\title{
Pre-colonial Elitism: A Study in Traditional Model of Governance in Akokoland
}

\author{
By Olusanya Faboyede*
}

\begin{abstract}
This paper examines the nature of traditional administration in pre-colonial Akokoland. Contrary to the view that traditional Yoruba society and other African peoples carried out their activities without planning because they were non-literate; there is sufficient evidence that pre-colonial Akokoland had dynamic patterns and result oriented models of administration. Prior to European colonialism, Akoko society was structurally arranged and positively administered for the benefit of the people of the region. The method of data analysis employed in the study is the historical approach of simple, descriptive and analysis of historical data. The paper concludes that pre-colonial Akokoland and African states generally had their own unique models or systemic pattern of governance before the commencement of colonial enterprise. The paper, therefore recommends that pre-colonial history of various communities in Nigeria, including Akokoland should be given more scholarly attention in order to preserve indigenous culture and to show that the people had a history worthy of study before the era of colonisation.
\end{abstract}

\section{Introduction}

Existing literature on the purpose of European interaction in Africa and, Akokoland in particular, suggests that Africa had no culture, uncivilised ${ }^{1}$ and needed some form of 'cultured' transformation. The people of Akokoland needed change and continuity as a progressive and dynamic society. This was the objective that was behind the application of elitism for the growth of their society. The adoption of elitism on the administration of the people of Akokoland was a key factor. The basis of its application centered on secret oath $(a w o)^{2}{ }^{2}$ Secrecy was the watchword of pre-colonialism in Akokoland. Thus, pre-colonial period was a landmark in the evolution and practice of elitism among communities in Akokoland. Towns and villages in Akoko region are situated on the frontier zone of northeastern Yorubaland ${ }^{3}$. It comprised fortyfive towns and villages ${ }^{4}$. It served as the major instrument to administer social justice and offered services to the people before it was disrupted and abandoned by the western civilisation. In that direction, the paper espouses the adoption

${ }^{*}$ Senior Lecturer, Adekunle Ajasin University, Department of History \& International Studies, Nigeria.

1. O E. Uya, "Decolonising African History and Culture", The Nigerian Chronicle, Saturday, December, 1974, p. 8 \& S. Oluwole, "An Ifa Divined has the Same Intellectual Depth as a Professor", The Nation, Saturday, June 28, 2008, 16.

2. J. O. Awolalu and P.A. Dopamu, West Africa Traditional Religion (Ibadan: Onibonoje Book Industries Ltd, 1979), 80.

3. R.A. Olaniyan, "Foreword", in Northeast Yorubaland: Studies in the History and Culture of a Frontier Zone, ed. A. Olukoju, et.al. ((Ibadan: Rex Charles Publication, 2003), viii.

4. O. Faboyede, "The Akoko Elite, 1900 - 1960", Thesis submitted to the Department of History and International Studies, Ekiti State University, Ad0-Ekiti, Nigeria, March 2013, 88. 
and role of the traditional council of chiefs and elders, babalawo (local intelligentsia), cult and chief priest, babaloja and iyaloja (men and women market leader) in the political affairs and adjudicating of justice in Akokoland. Akokoland is situated on the frontier zone of northeastern Yorubaland.

The traditional council of chiefs and elders headed by the king $(o b a)$ was (and is still) the head of monarchy. The king's stool was created and the council of chiefs and elders was placed under the Authority of the king. In Akoko region, every quarter was placed under the traditional chiefs who were responsible for the day-to- day administration of his domain. The council was a composition of chiefs and elders that always assisted the king (oba) in the disposition of justice. Punishments were meted out on offenders according to the gravity of offence to serve as deterrence to evil doers. ${ }^{5}$ In most cases, litigants were required to swear to an oath before the hearing of their cases in order to prevent distortion of facts. In civil cases, according to oral source, parties were required to deposit fees of cowries. ${ }^{6}$ The amount varied from one town and village to another. This explained that the people of Akokoland, especially the Aika community in extremities of northeastern Yorubaland ${ }^{7}$ appreciated the usefulness of cowry shell for transaction of goods and services, apart from using it for decoration and Ifa divination. ${ }^{8}$

Trial was also conducted by ordeal whereby the defendant was made either to drink 'sasswood' concoction (obo), ${ }^{9}$ or to swear to a deity. The ordeal was to make the defendant, if found guilty, reveal his or her guilt or else might die after seven days. Justice was administered for fair hearing and members of council of chiefs and elders usually performed social rites to find out the truth of any civil cases. The violation of societal norms and values (eewo) attracted death or severe penalties. Eewo (taboo) ${ }^{10}$ was used to strengthen the process of judicial matter among communities in Akokoland.

The nature of planning in the pre-colonial society of Akokoland allowed for balance of power in the traditional system of governance for communal integration and cohesion. The council of chiefs and elders was not autocratic and such 'ultra-democratic' organisation streamlined the political institution. Courts were established in the palace. The existence of palace court gave rise to the growth of elite or courtier class. The flute and drum that accompanied songs announced the presence of the $o b a$ and his chiefs and it illustrated the forms of oral literature in Akoko society. The song goes thus:

Odundun Omo a so ode dero

5. Interview held with Foluso Babadele, c. 75 years, he was interviewed at his residence, No. 87, Korowa street, Ayegunle-Oka on 10-07-2018.

6. For more details on the value of cowry as a medium of exchange, see T. Zeleza, $A$ Modern Economic History of Africa, vol. 1 (Senegal, Dakar; Council for the Development of Social Science Research in Africa (CODESTRIA), 1993), 282-284; M. Johnson, "The Cowries Currencies of West Africa", part 1, Journal of African History, xi, no 1(1970): 17-49.

7. R.A. Olaniyan, "Foreword," in A. Olukoju, et.al. (ed.), Northeast Yorubaland: . ., viii.

8. Ifa is a divination system. It is a system of codification of Yoruba thoughout and a system of storing knowledge. More so, it can be described as a literay corpus and a compilation of human ideas that touch on many aspects of human life like religion, marriage, politics, among others. See, S. Oluwole, "An Ifa Divined has the Same. . .", 16.

9. Interview held with Foluso Babadele cited.

10. J.O. Awolalu, and P.A. Dopamu, West Africa Traditional Religion, ..., 212. 
Omo ataye ro bi oko,

Omo ogborogodo omi,

Omi egingbon ko se

Eni mo gbigbo, a gbo so ri arare. ${ }^{11}$

Translation: the odundun (peacemaker or mediator) that makes life easy:

The son that makes things easy,

the son of provision,

rejecting wisdom is not possible

Whoever is rejecting wisdom has done that to his peril.

The palace songs were seen as a means of metaphorically reporting the activities in the palace court ${ }^{12}$. The king enjoyed confidence and legitimacy from Akoko people as determined by the functional role of the other elites in his palace. Lawal succinctly concluded that the traditional rulers then were: rulers in every sense of the word recognised and revered by the people of their respective areas of authority ${ }^{13}$.

\section{Conceptual Framework}

In this paper, elitism is associated with norms and values that depict the practice of group integrity and patriotism among the people of Akokoland for the purpose of good governance. However, its adoption transcends the British rule in Akokoland. Also, the intelligentsia is a product of elitism that refers to sage people in Akokoland. The sage is a group of people that assist the council of chiefs and elders in Akoko society during the period of peace or in time of crisis $^{14}$.

\section{Babalawo (the Intelligentsia) in pre-colonial Akoko Society}

The discussion on the intelligentsia (babalawo) was centered upon the intellectual and not on the cultic aspect. The babalawo (intelligentsia) in this context referred to a group of people historically known as onimo tabi amoye

11. Interview held with R. O. Jackson Sangobunmi, c. 85 years, arokin (the rhapsodist). He was interviewed at his residence, No. Y/28, Ogotun Street, Oge community, OkeagbeAkoko on 20-07-2018. For more details on odundun, see A. Babalola and O. Alaba, A Dictionary on Yoruba Personal Names (Lagos: West African Book Publishers Ltd, 2003), 676; R. C. Abraham, Dictionary of Modern Yoruba, (London: Hodder \& Stoughton, 1946 \& 1962), 505 .

12. See O.B. Olaoba, "Problem of Writing Palace History in Yorubaland," OLOTA: Journal of African Studies, I, no. 1(1995): 27-28.

13. N.A. Lawal, "The Position of the Chiefs," in Nigeria since Independence: The First Twenty Five Years, vol. 1, The Society, ed. Usman (Ibadan: Heinemann Educational Books (Nig.) Limited, 1989), 69-77.

14. For more details on the meaning and adoption of elitism in Akokoland, see O. Faboyede, "Elitism in Pre-colonial Akoko Society: It's Disorientation from Socio-cultural Value in Contemporary Akoko," Lumina, 22, no. 1(2011): 250 - 252. 
(wise person or sage) in the study of Akoko socio-political history ${ }^{15}$. There are two categories of babalawo in Yorubaland, including Akokoland. The examples are awo olodu and awo elegan. Awo olodu is the devoted Ifa diviner, while awo elegan are the non-professionals. In Akokoland, awo elegan are known as asawosagbe (combiner of devotional duties with farming). ${ }^{16}$ Oral evidence aptly puts it that they are knowledgeable in the art of divination and traditional governance for peaceful co-existence, but not initiated into Ifa cult. This group of traditional elite in another word can simply be referred to as the sages who were (and are still) the repertoires of knowledge. ${ }^{17}$

The examination of babalawo in this paper is concerned about the contradistinction, as stated by $\mathrm{W}$. Bascom that only men can become babalawo $^{18}$. He claimed that he never met a single female Ifa priestess during his field studies between 1937 and 1965. In contrast to his claim, there are many female Ifa priestesses called iyanifa ${ }^{19}$. Again, awo is often used as a gender-neutral reference to individual iyanifa or babalawo. In planning and administration of pre-colonial Akoko society, the intelligentsia as were sages whose vision and insight led them to look at life from a quasi-philosophic angle through the use of incantation. Incantation was spontaneous words that were spoken on political matters to guide the pre-colonial Akoko society for better administration for transformation and growth. The Akoko people have always had recourse to one form of divination or the other with a view to resolving personal, family or societal problems. It is indeed necessary for babalawo (the intelligentsia) to consult or approach Ifa oracle to configure and address the societal problems. Bascom rightly observed that:

of all the methods of divination employed by the Yoruba,

Ifa is regarded as the most important and the most reliable.

The honesty or knowledge of individual babalawo (intelligentsia)

may be questioned, but most are highly esteemed, and the system

itself is rarely doubted. The number of babalawo is a reflection

of the patronage they receive and a measure of the influence they wield ${ }^{20}$.

In view of Bascom's observation, the intelligentsia occupies an enviable position among the Akoko elite because of the disposition of the wealth of their wisdom. It is noteworthy to state that in the past, where letters were not known and the languages not reduced to writing, the aged were the repositories of wisdom, knowledge and of the people's history. Akinjogbin stressed the important position this group of people occupied when he asserted that any

15. B. Ajayi, "Ifa Divination Process," in ed. L.O.Adewole (IFA and Related Genres, (South Africa: The Center for Advanced Studies of African Society (CASAS), 2001), 4142.

16. Interview held with P. A. Afe, the Oloyi of Oyi, Irun-Akoko, c. 106 years, at his residence, No. L/51, Oyi Street, Irun-Akoko on 28-03-2018.

17. Ibid.

18. See W. Bascom, Ifa Divination: Communication between Gods and Men in West Africa, (London: Indiana University Press Bloomington, 1969), 11.

19. Interview held with Asisat Rasheeed, C. 32years, No, 1,Akunmi Street, AkungbaAkoko on 12-07-2018.

20. Bascom, Ifa Divination . . . , 6-11. 
person who had no knowledge of his people's history and land is like an uprooted plant which is unlikely to grow no matter how much water that is poured on $i t^{21}$. Thus, the role of babalawo (the local intelligentsia) in this study is very crucial to the socio-cultural and political history of Akokoland ${ }^{22}$.

It is necessary to mention that natural knowledge in divination and wise sayings were the prominent attributes of the intelligentsia. Babalawo as Ajayi noted in his work ${ }^{23}$, was a trained dedicated priest of Ifa. However, some of the Ifa priests were not trained; but some families were gifted. According to an informant, the practice of Ifa divination was inherited by members of her paternal family ${ }^{24}$. Again, the unique position of babalawo in the political affairs of Akokoland cannot be overemphasised. Babalawo is knowledgeable about the traditions of his people. He has the wisdom to reflect on the past and foretell about the present and the future of administration. To the sage, it was possible to peep into the seen and the unseen to avoid calamity in the society. In addition, the intelligentsia usually made allusions to historical value of wisdom and is reminiscent of mystique power in Akoko society ${ }^{25}$. The claim here is depicted in folklore of the people. It goes thus:

Oloye la a peyere

Oloye la a peyere

Eleto la a patori

Aranmoleti la a perai. ${ }^{26}$

Translation: The wise one is what we call the Iyere (black pepper).

The wise one is what we call Iyere (black pepper).

The order is what we call the atori (plant),

One who reminds children is what we call eeran plant (phrynium).

By the late nineteenth century, babalawo became a respected individual group saddled with the responsibility of protecting the Akoko community by performing propitiatory sacrifices to ward off evil in any towns and villages. The intelligentsias were generous, faithful and good traditional counsellors to the council of chiefs and elders on fundamental issues like settling of marriage, chieftaincy and land disputes among the Akoko community. On this background, the paper pointed out how babalawo played a key role in the practice of elitism and thus shed light on its usefulness and codification in the

21. I.A. Akinjogbin, Milestones and Social System in Yoruba History and Culture, (Ibadan: Olu-Akin Publishers, 2002), p. 3.

22. Interview held with Lawal Peters, c. 51 years, farmer and Prophet. He was interviewed at No. 32, Ese-odo quarters, Iwaro-Oka on 12-07-2018.

23. Ajayi claimed that the babalawo was trained and dedicated Ifa priests in the Yoruba community of Nigeria. See Ajayi, "Ifa Divination Process," in Adewole (ed.), IFA and Related Genres......, p. 41.

24. Interview held with Iyalode, c. 60 years. She was interviewed at her residence, AjowaAkoko on 20-07-2018.

25. See S. O. Arifalo, "Historical Consciousness in Preliterate Nigerian Societies", in G.O. Oguntomisin and S. A. Ajayi (eds.), Readings in Nigerian History \& Culture (Ibadan: Hope Publications, 2002), 25, 28-31.

26. Interviewed held with Lawal Peters cited. 
adminstartion of fair justice for peaceful co-existence of the inhabitants of Akokoland in pre-colonial period and even beyond.

Oral evidence suggested that the inhabitants of Akokoland communities in the southeast and eastern parts of Akoko $^{27}$ attested that the head of the intelligentsia (olori-awo or head of elders (olori agba ilu) group in the community occupied a significant position, especially concerning the coordination and execution of spiritual duties such as rites, rituals ceremonies, which were connected with the offering of sacrifices for the propitiation and veneration of deities and ancestral spirits.

The intelligentsias were consulted in every important event, private or public, such as giving advice on marriage system among Akoko communities like in other parts of Yorubaland ${ }^{28}$. In the same vein, the cult and chief priests played important role in the betrothal of marriage system by consulting Ifa. Marriage relationship was (and is still) ascertained by the Ifa chief priest whether a match was desirable for a boy or a girl, before the parents gave their consent to the marriage ${ }^{29}$. The option to marriage was different from the precolonial society and urban cities. For instance, in urban or cosmopolitan societies like in Lagos, a boy and a girl could agree to marry each other without seeking their parents' consent. This neglect of not consulting with their parents before such marriage sometimes led to divorce, because marriage was (and is still) believed to be an affair of the family and it is a unifying factor in the society. Marriage as an institution occupied a unique place in the social life of the inhabitants of Akokoland. It is an extension of the extended family, rather than the husband and wife. ${ }^{30}$ It was a form of relationship to integrate the society. Love and spirit of communalism were the attributes of marriage in Akokoland, as against the separation of the extended families from the building of the new family as introduced by the western culture.

\section{The Cult Priest and the Chief Priest in Pre-colonial Akokoland}

An analysis of the nature and functions of the cult and chief priest are very germane in the understanding of the traditional model of governance in Akokoland. The term 'cult' identifies a pattern of ritual behaviour in connection with prayers, sacrifice, votive offerings, and procession and with specific objects within a framework of spatial and temporal rules. The nature of offering and sacrifice depend on the nature of the omen. On revelation, sacrifices were offered by the cult and chief priests to propitiate the divinities orisa, a sacred object of worship, a deity to make the society to be better off. The individual Akoko man will not venture upon any important business until he has consulted the Ifa oracle through its priest. Every facet of the Akoko community consulted

27. Interview held with Oladunni Akerele, c. 102 years, herbalist and farmer. He was interviewed at his residence, Y/38, Okeigbala Street, Oge community, Okeagbe on 20-072018.

28. N. A. Fadipe, The Sociology of the Yoruba ( Ibadan: Ibadan University press, 1970), 275.

29. Ibid, pp. 16, 72 \& 193.

30. Interview held with Iyalode cited. 
If $a$ for one reason or another, for instance, orisa oko (the patron of farmers) resorted to the cult or chief priest of Ifa to know the performance of farmers ${ }^{31}$.

The cult priests were appointed by the members of their family and shared a good deal of the council of chiefs and elders' restriction through the performance of ritual. In the entire community of Auga, Chiefs Shaba, Balogun and representatives of each quarter acted as advisers on issues that were affecting them as well as military engagement because it had a link to the council of $o b a$. The cult and chief priests were very reputed in their dexterity and methods of consultation to secure the unity and peace of the community through sacrifice. The contributions of cult priests and chief priests were inevitable in the socio-cultural affairs of the people of Akokoland. Chief P.A. Afe, the Oloyi of Irun affirmed that the influence of cult (Ifa) priest as one of the traditional elites is very unique. He further emphasised that Ifa was also mainly concerned to promote understanding of indigenous traditional religion. He went further to state that the cult priests utilised their innate resources, divergent and rare experience to aid the people that were in need of spiritual support or guidance ${ }^{32}$. The cult priest and chief priest are well-known for handling cases and problems that can be linked to supernatural causation ${ }^{33}$. In addition to the claim of Chief Oloyi, Doyin Wenger opined that the chief priests consulted the gods and, acting as diviners helped people to solve their problems and performed rituals when necessary ${ }^{34}$. For the chief and cult priests to attain their statues, iyere Ifa is chanted by the devotees of orunmila when they came together during a festive period ${ }^{35}$.

The relevance of the adoption of Ifa divination to discover the unknown is reposed in the belief system of Akoko people in Ifa, wherein every human's success depends on his or her ori (personal destiny) ${ }^{36}$, which he or she obtained by kneeling before Olodumare, the creator. Orunmila (the divinity of destiny) knew everything about human's well-being and could, therefore, provide insight into his or her success or failure through his chief priests. Reason for this was that orunmila was omniscient and capable of altering human's destiny. ${ }^{37}$ This accounted for his praise song or title in Akoko's pithy saying; Okitibiri apajo-iku-da (the great changer, he who alters the day of death). It is necessary to say that it was orunmila, the divinity of eleri-ipin (the witness or advocacy of human destiny) that gave details on how human destiny could be

31. Interview held with Oladunni Akerele cited.

32. Interview held with P.A. Afe, the Oloyi of Oyi cited.

33. M. O. Adekson, The Yoruba Traditional Healers of Nigeria (Routledge: Taylor and Francis, 2003), 66.

34. See Taiwo Abiodun, "Inside Susan Wenger Shrine," The Nation, Sunday, April 24, 2011, 29.

35. See O. Olatunji, Features of Yoruba Oral Poetry (Ibadan: University press Limited, 1984), 7 \& 109; W. Abimbola, "Ifa as a Body of Knowledge and as Academic Discipline", Lagos Notes and Records: University of Lagos Bulletin of African Studies, vol. 2, no. 1: 36-40.

36. Interview held with M A. Adamu, c. 60+ years, he was interviewed at his residence, No. 03/ A23, Ayase Street, Agbaluku-Arigidi on 10- 05- 2018.

37. J.O. Awolalu, and P.A. Dopamu, West Africa Traditional Religion, . . ., 79. 
fulfilled through Ifa divination. ${ }^{38}$ There is a popular adage in the foklore of Akoko people to this claim that akunleyan ni adayeba; a kunle a yanpin, a dele aye tan, oju $n$ kan gbogbo wa, meaning that which is chosen kneeling is that which is experienced on getting into the world no matter how impatient people get thereafter to make it in life ${ }^{39}$. No matter the level of impatience, Akoko people believe it is ori (destiny) that determines a human success or failure in life. The cult and chief priests uphold and honour the Akoko philosophical concept of elitism in their routines and belief system. The importance of cult and chief priests explained their contributions as conceived in the themes of disobedience and sacrifice in the idea of governance during pre-colonial period.

The cult differences notwithstanding, members of the cult had traditionally organised themselves into a regimented priesthood. In Akoko tradition, the cult and chief priests had been recognised as promoters of unity. Cult in this primary sense is literally the 'care' owed to the gods and the shrine. Edibles and drinks such as snails, tortoise, palm wine and water might be prescribed as sacrifice of propitiation, thanksgiving and praise to the oracle of orunmila (the oracle divinity of Yorubaland) in matters of knowledge. ${ }^{40}$ There were bodies of cultic chiefs, which ensured the purity and spiritual guidance of the Akoko society. Among the communities in the frontier zone of northeastern Yorubaland, sacrifices constituted the forms of political organisation, aristocratic privileges. As O. Olatunji has claimed, sacrifices were offered to propitiate, appease or send messages to the gods, to ward off sickness. He went further to say that the traditional rulers sometimes offer human sacrifices to secure the protection of the royal family ${ }^{41}$.

\section{Babaloja and Iyaloja (Market Men and Women Leaders) in Pre-colonial Akoko Society}

This part discusses the role of babaloja and iyaloja (market men and women leaders) in the management of economy in Akokoland. The title holders were in charge of economic activities in pre-colonial Akoko. Their role in the traditional governance was connected with the responsibilities and duties they played at the market. Market, according to Hodder was simply referred to as a public place in which commodities were bought and sold $42^{42}$.The study examines their functions because of the interdependent nature of the council of chiefs and elders among the Akoko communities. In Akoko community, the

38. Interview held with Jayeola Ajulo (Alias Faari), No. 8, Iromi quartes, c. 74 years, Ipesi -Akoko. He was interviewed at his residence on 05-06-2018.

39. Interview held with $\mathrm{Pa}$ Lawal, c. 75 years. He was interviewed at his residence opposite Ajuta Grammar School, Ogbagi-Akoko on 20-07-2018.

40. J.O.Awolalu and P.A. Dopamu, West Africa Traditional Religion, ..., 31 \& 54, 79.

41. O. Olatunji, "Slavery and Human sacrifices in Yorubaland: Ondo Example," Journal of African History, November 1, 2005 \& http//www. accessorylibrary.com (02/ 03/ 2009.

42. B.W. Hodder and U.I.Ukwu, Markets in West Africa (Ibadan: Ibadan University Press, 1979; L.M. Olayiwola, "A Case for the Renewal of Traditional Markets in Ibadan," Odu, no. 28, July 19195Market. 
utilitarian value placed on women cannot be underestimated. Due to the significant contributions and place of women in Yoruba historiography, it is necessary to investigate the contributions of iyaloja (market women leader) and its male counterpart. In this part of Yorubaland, women are highly productive and of great asset to their nuclear family.

Trading and organisation of the markets were remarkable features of agricultural system in pre-colonial Akoko society. Market was usually located at the village square and palace ${ }^{43}$. Trade was a dominant factor in inter-state relations. Commerce served as a bond of good relations among Akoko communities. Some towns and villages, namely, Ikare, Arigidi, Oba and Isua attracted traders from different parts of the Yoruba-speaking towns and Nupe area. Markets in these places were strategically located intersecting Okeluse at the estuary of Akokoland. Towns, villages and markets were connected by narrow footpaths that were used by traders. They carried wares on their heads. Each town or village took care of the section of the footpaths within its territory. In times of peace, traders and travellers walked freely on the roads without fear of molestation, except during wars. During this period, traders went together in large numbers and were escorted by armed soldiers ${ }^{44}$.

The iyaloja and babaloja were very important in the economic growth of Akoko society during pre-colonial period. The position of babaloja and iyaloja in the building of market system and commercial activities cano be overemphasized. They participated in long distance trade ${ }^{45}$. In contrast, A.G. Hopkins claimed that women were shackled and thus, prominent in domestic (chores) trade, because of inadequate time and skill. ${ }^{46}$ This is a Eurocentric view and pre-conceived idea about the performance of women in the local economy. It is important to point out that women had limited role to play with their male counterparts as they were described as the weaker vessels. Olajubu, however, attested to the conceptualisation of women's crucial roles in sociocultural aspect of the Yoruba, including Akokoland. ${ }^{47}$

In the pre-colonial Akoko communities, Ibadan and Ekiti traders dominated slave markets. Nupe itinerants traded in grains such as corns and maize, pepper and kolanuts. The success of Nupe traders made them establish a colony (isale-tapa) in Arigidi, ${ }^{48}$ northwest of the Akoko region. The Ijebu traders and merchants were very prominent by extending their marketing

43. O. Faboyede, "Trade and Markets among the Akoko Communities in the Precolonial Period," Journal of Law and International Security, 4, no. 1(2010): 37-39. (Ekpoma: Department of Public Law, Ambrose Alli University).

44. I.A. Akinjogbin and S. Osoba (eds.), Topics on Nigerian Economic and Social History (Ile-Ife: University of Ife press, 1980): 42.

45. B. Agiri, "Slavery in Yoruba Society in the Nineteenth Century", in The Ideology of Slavery in Africa, ed. P. E. Lovejoy (Sage: Beverly Hills, 1981).

46. A. G. Hopkins, An Economic History of West Africa (London: Longman Group Limited, 1973), 56.

47. O. Olajubu, "Women in the Yoruba Religious Sphere," African Studies Review, December 1, 2006. Also, see S. Johnson, The History of the Yorubas: from the Earliest Times to the Beginning of the British Protectorate (Lagos: CSS Limited, 1921), 31 \& 112.

48. O. O. Ilesanmi, "Population and Settlement Pattern in Akoko," unpublished Project Nsukka, 1964, 8 \& C.O. Akomolafe,"Akoko under British Rule, 1900-1935", Thesis Submitted for the Degree of Philosophy (History), University of Ife, Ile-Ife, 1976, 14. 
influence in Akokoland. Ijebu traders were pre-occupied with the sale of cash crops, like cocoa, coffee, oil palm, palm kernel and kolanuts. This remarkable task gave them commercial dominance over their hosts ${ }^{49}$.

At a point, Ijebu trade consuls (the Agurin) ${ }^{50}$ lived among the Akoko people and established flourishing trade centres, locally known as isale-Ijebu quarter. Also, they formed associations (egbe omo Ijebu), built warehouses and contacts with business partners. ${ }^{51}$ The leaders of Ijebu associations worked according to the market rules and regulations. The associations also assisted traders during the time of crisis. The associations gave them the privilege to relate with the political authorities in Akokoland. Thus, Falola aptly described Ijebu traders as traders who possessed an "irrepressible flair for trading",52. Ijebu traders exploited inter-state commercial activities with their expertise and enterprise in trading activities. It was gathered that the organised commercial activities took the form of multi-cultural dimensions.

Be that as it may, Ijebu traders and merchants played middlemen role between Akoko traders and British merchants who exported oil palm to their countries $^{53}$. Against this backdrop, they became rivals. Ijebu traders, however, possessed coin money and paper currency to finance their trade. Their trading tactics enabled them to further spread their sphere of influence in the Akoko region. Aside, prices and varieties of agricultural goods were regulated at the market under the caprices of the babaloja and iyaloja. In that manner, Osele market became inter-regional market and traders exchanged their commodities at intervals of nine days. Oral traditions substantiated that transactions were in form of trade by barter and to a certain degree, the use of owo eyo (currency shell) was applicable ${ }^{54}$. In effect, better economic relations were encouraged and developed in the earliest years of the twentieth century.

For effective planning, babaloja had guild men who were in charge of strategic routes to secure the payment of tolls and sometimes supervised the movement of the external traders from Ibadan, Ekiti, Ijebu and Ilesa ${ }^{55}$. The

49. O. Faboyede, "The Akoko Elite, 1900 - 1960", . ., 88

50. Interview held with Chief (Mrs.) Florence Olotu, the Iyaloja in Akokoland, c. 82 years. She was interviewed at her residence, No. 7, Owanikun quarters, Ikun Akoko on 12 07-2018.

51. See T. Falola, "Warfare and Trade Relations between Ibadan and the Ijebu in the Nineteenth century," in Warfare and Diplomacy in Pre-colonial Nigeria: Essays in Honour of Robert Smith, ed. Falola (USA: University of Wisconsin-Madison, 1992), 26 \& A. L. Mabogunje, "The Ijebu", in The History of Ibadan, ed. P. C. Lloyd, et.al. (London: Cambridge, 1967), 26.

52. See T. Falola, "Warfare and Trade Relations Between Ibadan and the Ijebu in the Nineteenth Century," in Warfare and Diplomacy..., ed. Falola, 26; A. L. Mabogunje, "The Ijebu," in The History of Ibadan, ed. P. C. Lloyd, et.al., (London: Cambridge, 1967), 85.

53. A. Mabogunje, "The Land and Peoples of West Africa", in History of West Africa, vol. one, ed. J.F.Ade-Ajayi and M. Crowder (London: Longman, 1971), 23-29. Akoko.

54. Interview held with J.E. Ogungbe, the Elemurin of Emure quarter in Epinmi-

55. It is important to mention that the Ijebu middlemen controlled trade in Akokoland and transported farm produce to the British traders and merchants on the coast. The guilds in various towns and villages in Akokoland could not control the trade because of the porosity of Akoko borders, in spite of disunity among the Akoko elite. The commercial elite failed to control the fixed price. Besides, the Ijebu traders had much money to carry 
organisation of the guilds was based on the features of the trade, that is, the system of caravans and the payment of tolls. Toll fees and taxes on trade and traders offered Akoko communities important means of raising revenues and it provided revenues for the traditional rulers and their council of chiefs. However, the monarchs gave hospitality and protection to the traders ${ }^{56}$. The charges collected from the toll gates formed part of the revenues that were dispensed by the traditional rulers to run the affairs of their domains. Babaloja and iyaloja played important roles in provincial administration in terms of providing financial source to the kings to run the administration of their communities. The art of keeping or saving of money was also the role of iyaloja and babaloja. They organised a saving club like the esusu where money was saved and later given to its members for a fixed period of time ${ }^{57}$.

The contributions of iyaloja to the socio-cultural and economic affairs of the people of Akokoland fetched her highest title of iyaloja in the economic sphere. To that extent, the iyaloja wielded some political influence, although such political status differed from one community to another. Iyaloja officiated in the opening of new markets and she was regarded as the priestess of aje (god of money), and thus became iyalaje. She settled quarrels at the market place under her jurisdiction. It is, however, interesting to note that in Akokoland, the iyaloja constituted part of the membership of secret societies such as Ogboni cult and Onisagan associations in order to be more responsible for executive and judicial functions in the market place ${ }^{58}$. By dint of hard work and patriotism, she rose to the position of elitism in Akokoland. Her mastery in trading and selfless attitude was such that brought her closer to the women folk and the entire society ${ }^{59}$.

Similarly, babaloja involved in the fixing of the tariff or duties and determined the sharing formula of the proceeds. Since the booty of war could no longer be neither obtained nor new slaves be acquired as a result of cessation of wars, tolls became important to the chiefs, more than ever before. Hitherto, all towns and major settlements had boundary gates, which the traditional rulers considered to be desirable to the economic growth of their territories. On that background, babaloja and iyaloja as the representatives of the king maintained

out trading activities in Akokoland. As a result of this negligence both the Ijebu and Benin traders were able to extend their trading activities to Osele and Okeluse markets.

56. See D. Oguntomisin, "Warfare and Military Alliances in Yorubaland in the Nineteenth Century", in Warfare and Diplomacy: .., ed. Falola, 59. Also, see P. MortonWilliams, "The Oyo Yoruba and the Atlantic Trade 1670 - 1830", Journal of Historical Society of Nigeria, vol. 3, no. 1(1964): 41.

57. Fadipe, The Sociology . . ., 256. Esusu was very prominent in Akokoland. It was meant for capacity building by contributing sum of money on a monthly basis, which was given to selected contributors at the end of the month. The initiators were very common in Ikaramu, Ibaramu and Iyani communities. The method was a great convenience to the traders, because it encouraged the local traders to anticipate for saving up to a given amount of money for future expenses.

58. Interview was held with Florence Olotu, the iyaloja. She was consulted in all matters that concerned socio-economic activities at the market stall (place). She also went further to clarify that membership to secret societies was voluntary and optional. She was interviewed on 18th November, 2011.

59. Interview held with Florence Olotu cited. 
the traditional ownership of land in their community by preventing forceful possession of land in the community. This led to non-radical land ownership or redistribution. It is needless to mention that such social function had significant implications for the community's economic performance. The control of babaloja and iyaloja in trading activities marked a momentous shift in communal organization in Akokoland of northeastern Yorubaland. With the help of their guilds, led control over toll collection and tributes that were paid were seen, according to Ojo60 $0^{60}$, as manifestation of elite privileges that had been integrated onto the Akoko philosophy of elitism to develop the study area. Both babaloja and iyaloja sent tributes to the capital at the auspicious annual festivals in towns and villages in Akokoland, for example, during Ajagbo festival, which was virtually celebrated nearly in every town and village in Akokoland. The market leaders sent farm produce to the king which demonstrated their loyalty to the king. Towards the tail end of the pre-colonial period, iyaloja and babaloja had established themselves as astute politicians and nationalists. The economic structure provided sources of income and sustainability fro the market men and women The involvement of traders in economic management protected human dignity in particular men as the head of the family that fended for members of the family. Family structure had remained one of the basic political structures in Akokoland and, also the feature of elitism among the towns and villages communities in Akoko region since pre-colonial time till date. Thus, their contributions to the growth of towns and villages in Akokoland with the necessary progressive activities cannot be overemphasised.

\section{Conclusion}

This study has attempted a brief discussion of the intrinsic values of traditional model of governance in pre-colonial Akoko society and it examined the role of elitism in pre-colonial period in the socio-cultural growth of the Akoko communities and in the historical process in Yorubaland. It also provided literary connection to distortion and misrepresentation of the fact that the people of Akokoland had no history worthy of academic study ever before the introduction and establishment of colonial rule in Akokoland. The study found out that pre-colonial elitism had considerably contributed to reconstruction of traditional model of governance in Akokoland and the study local history. It is needless to say that the council of chiefs and elders was the pivot around which Akoko administration revolved. The traditional political association of chiefs and elders was an institution from which every developmental process started and even ended. No doubt, the status of council of chiefs and elders and its democratic nature ${ }^{61}$ as it were in other parts of

60. O. Olatunji, "Warfare, Slavery and the Transformation of Southeastern Yorubaland, c. 1820-1900", A Thesis submitted to the Faculty of Graduate Studies in Partial Fulfilment of the Requirements for the degree of Doctor of Philosophy, Graduate Progarm in History, York University, Toronto, Ontario, September, 2003, 153.

61. Fadipe, The Sociology . . ., 223. 
Yorubaland has been discussed. The institution participated in the administration of justice and preservation of indigenous culture in Akokoland, which was very essential to the integration of Akoko society. The study also discussed that the council of chiefs and elders led by the king was the political institution used to train subsequent leader in the past through babalawo, cult and chief priests to checkmate the excesses of the king. The iyaloja and babalaoja were used as the instruments of anti-social and economic activity on the market place. In the arrangement, such ordinances promote economic progress, orderliness that underlined peaceful co-existence in the place. From the above, it is evident that the intelligentsia preserved traditional histories or events, cosmology and administration. On this note, the intellectual ability and integrity of babalawo (the sage) revolved around the Akoko philosophy of omoluabi (a person of honour), an aspect of Akoko culture. The role and contributions of cult and chief priests in Akokoland are pointers to the democratic credentials of the region.

Assessing the traditional value of elitism, the pride of place in planning and art of governance has connected them to the past with the present and the present with the future as a single continuum in human experience. ${ }^{62}$ The model of governance in Akoko communities was built on the achievement of the past. The Akoko culture of omoluabi and indeed Yorubaland cannot be divorced from the Akoko people's governance arrangement became the culture of omoluabi that was demonstrated from the point of view of Yoruba culture and its contribution to African philosophy. The study, therefore, concluded that the application of elitism in traditional model of governance in Akokoland had contributed immensely to the advancement of the study of Akoko history of northeastern Yorubaland in Yoruba history in such a way that it will provoke further research.

\section{Bibliography}

Abimbola, W. "Ifa as a Body of Knowledge and as Academic Discipline." Lagos Notes and Records, 2, no. 1(1968): 30-40.

Abiodun, T. "Inside Susan Wenger Shrine." The Nation, Sunday, April 24, 2011.

Adekson, M. O. The Yoruba Traditional Healers of Nigeria. Routledge: Taylor and Francis, 2003.

Agiri, B. "Slavery in Yoruba Society in the Nineteenth Century." In The Ideology of Slavery in Africa, edited by P. E. Lovejoy. Sage: Beverly Hills, 1981.

Ajayi, B. "Ifa Divination Process." In IFA and Related Genres, edited by L.O.Adewole. South Africa: The Center for Advanced Studies of African Society (CASAS), 2001.

Akinjogbin, I.A. and S. Osoba. (eds.). Topics on Nigerian Economic and Social History. Ile-Ife: University of Ife Press, 1980.

Akinjogbin, I.A. Milestones and Social System in Yoruba History and Culture. Ibadan: Olu-Akin Publishers, 2002.

Akomolafe, C.O. "Akoko under British Rule, 1900-1935. Thesis Submitted for the Degree of Philosophy (History), University of Ife, Ile-Ife, 1976.

62. J. Osuntokun, "A Nation without History", The Nation, 2 April, 2009, 17. 
Arifalo, S. O. "Historical Consciousness in Preliterate Nigerian Societies." In Readings in Nigerian History \& Culture, edited by G.O. Oguntomisin and S. A. Ajayi. Ibadan: Hope Publications, 2002.

Awolalu, J. O. and P.A. Dopamu. West Africa Traditional Religion. Ibadan: Onibonoje Book Industries Ltd, 1979.

Babalola A. and O. Alaba. A Dictionary on Yoruba Personal Names. Lagos: West African Book Publishers Ltd, 2003.

Bascom, W. Ifa Divination: Communication between Gods and Men in West Africa. London: Indiana University Press (Bloomington), 1969.

Faboyede, O. "Trade and Markets among the Akoko Communities in the Precolonial Period." Journal of Law and International Security, 4, no. 1(2010). Ekpoma: Department of Public Law, Ambrose Alli University.

Faboyede, O. "The Akoko Elite, 1900 - 1960." Thesis submitted to the Department of History and International Studies, Ekiti State University, Ad0-Ekiti, Nigeria, March 2013.

Faboyede, O. "Elitism in Pre-colonial Akoko Society: It's Disorientation from Sociocultural Value in Contemporary Akoko." Lumina, 22, no. 1, (2011): 250 - 252.

Falola, T. "Warfare and Trade Relations between Ibadan and the Ijebu in the Nineteenth century." In Warfare and Diplomacy in Pre-colonial Nigeria: Essays in Honour of Robert Smith. USA: University of Wisconsin-Madison, 1992.

Hodder, B.W. and U.I. Ukwu. Markets in West Africa. Ibadan: Ibadan University Press, 1979.

Hopkins, A. G. An Economic History of West Africa. London: Longman Group Limited, 1973.

Ilesanmi, O. O. "Population and Settlement Pattern in Akoko." Unpublished Project Nsukka, 1964.

Johnson, S. The History of the Yorubas: From the Earliest Times to the Beginning of the British Protectorate. Lagos: CSS Limited, 1921.

Johnson, M. "The Cowries Currencies of West Africa, part 1". Journal of African History, xi, no 1 (1970): 17-49.

Lawal, N. A. "The Position of the Chiefs." In Nigeria since Independence: the First Twenty Five Years, vol. 1, The Society, edited by Yusufu Bala Usman. Ibadan: Heinemann Educational Books (Nig.) Limited, 1989.

Mabogunje, A. L. "The Ijebu." In The History of Ibadan, edited by P. C. Lloyd, et.al. London: Cambridge, 1967.

Mabogunje, A. "The Land and Peoples of West Africa." In History of West Africa, vol. 1, edited by J.F.Ade-Ajayi and M. Crowder. London: Longman, 1971.

Morton-Williams, P. "The Oyo Yoruba and the Atlantic Trade 1670 - 1830." Journal of Historical Society of Nigeria, 3, no. 1(1964).

Oguntomisin, D. "Warfare and Military Alliances in Yorubaland in the Nineteenth Century." In Warfare and Diplomacy in Pre-colonial Nigeria: Essays in Honour of Robert Smith. USA: University of Wisconsin-Madison, 1992.

Olaniyan, R.A."Foreword." In Northeast Yorubaland: Studies in the History and Culture of a Frontier Zone, edited by A. Olukoju, Z. O. Apata and O. Akinwumi. Ibadan: Rex Charles Publication, 2003.

Olaoba, O. B. "Problem of Writing Palace History in Yorubaland." OLOTA: Journal of African Studies, I, no. 1(1995).

Olatunji, O. Features of Yoruba Oral Poetry. Ibadan: University Press Limited, 1984.

Olatunji, O. "Slavery and Human sacrifices in Yorubaland: Ondo Example." Journal of African History, 46, no 3(2005): 379-404. 
Olajubu, O. "Women in the Yoruba Religious Sphere." African Studies Review, December 1, 2006.

Olayiwola, L.M. "A Case for the Renewal of Traditional Markets in Ibadan." Journal of West African Studies, no. 28(1985): 71-79.

Oluwole, S. "An Ifa Divined has the Same Intellectual Depth as a Professor." The Nation, Saturday, June 28, 2008.

Osuntokun, J. "A Nation without History." The Nation, 2 April, 2009.

Uya, O E. "Decolonising African History and Culture." The Nigerian Chronicle, Saturday, December, 1974.

Zeleza, T. A Modern Economic History of Africa, vol. 1. Senegal, Dakar; Council for the Development of Social Science Research in Africa (CODESTRIA), 1993. 
